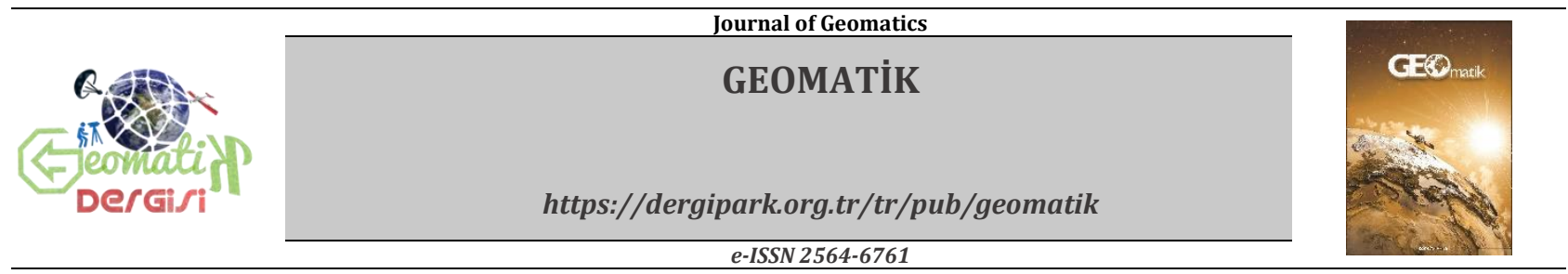

\title{
Arazi Toplulaştırma Projelerinin Ekonomik Analizi: Üçhüyük Mahallesi, Çumra- Konya- Türkiye Örneği
}

\author{
Tayfun Çay ${ }^{* 1}$, Ramazan Yoldaş Satılmış² \\ ${ }^{1}$ Konya Teknik Üniversitesi, Mühendislik Fakültesi, Harita Mühendisliği Bölümü, Konya, Türkiye \\ 2Pamukkale Üniversitesi, Çameli Meslek Yüksekokulu, Mimarlık ve Şehir Planlama Bölümü, Denizli, Türkiye
}

\author{
Anahtar Kelimeler \\ Arazi Toplulaştırması \\ Ekonomik Analiz \\ Toplulaştırma Faydaları \\ Tarımın Geliștirilmesi
}

\begin{abstract}
ÖZ
Arazi toplulaştırma projeleri sonrasında elde edilen ekonomik kazançlar hem tarım hem de ülke ekonomileri için oldukça önemlidir. Arazi toplulaştırma projelerinin artırılması ve ülke genelinde yaygınlaşmasının sağlanması açısından arazi toplulaştırma projelerinin getirdiği ekonomik kazançların özümsenmesi oldukça önemlidir. Bu çalışmada, Konya İli Çumra İlçesi Üçhüyük Mahallesinde yapılan arazi toplulaştırma projesi incelenerek yapılan toplulaştırma çalışmasının ekonomik analizleri yapılmıştır. Çalışmada çiftçilerle yapılan anketler ve proje sahası bilgileri incelenmiştir. Ayrıca toplulaştırma çalışmalarının işletmeler üzerindeki etkilerinin belirlenebilmesi için işletmeler büyüklüklerine göre 3 gruba ayrllarak işletmeler üzerinde gayri safi üretim değeri, gayri safi hasıla, işletme masrafları, saf hasıla ve net kar kriterlerine göre analizler yapılmış büyük işletmelerin toplulaştırma çalışmalarından daha büyük kar elde ettiği bulunmuştur. Analizler yapılırken önceki yıllarda yapılan çalıșmalarla da karşılaștırmalar yapılmıștır.
\end{abstract}

\section{Economic Analysis of Land Consolidation Project: Üçhüyük District, Çumra-Konya-Turkey Case}

\section{Keywords:}

Land Consolidation

Economic Analysis

Benefits of Consolidation

Development of Agriculture

\begin{abstract}
Economic gains after land consolidation projects are important for both agriculture and national economies. In order to increase land consolidation projects and spread them across the country, it is important to assimilate the economic gains of land consolidation projects. In this study, the land consolidation project in Üçhüyük Quarter of Çumra District of Konya was studied and analyzed. Surveys conducted with farmers and project area information were examined. In addition, in order to determine the effects of the consolidation activities on the enterprises, the enterprises were divided into 3 groups according to their size and analyzed on the basis of gross production value, gross product, operating costs, pure product and net profit criteria. While making the analyzes, comparisons were made with previous studies.
\end{abstract}

*(tcay@selcuk.edu.tr) ORCID ID 0000 - 0002 - 4661 - 5583 (rsatilmis@pau.edu.tr) ORCID ID 0000-0003-2907-4022
ÇAY, T., SATILMIŞ, R. (2020). Arazi Toplulaştırma Projelerinin Ekonomik Analizi: Üçhüyük Mahallesi, Cumra- Konya- Türkiye Örneği. Geomatik 5 (2), 112-119. DOI: 10.29128/geomatik. 581531 Retrieved from https://dergipark.org.tr/tr/pub/geomatik/issue/52495/581531 


\section{GíRiş}

Dünya nüfusunun bir milyara yükselmesi binlerce yıl sürmesine rağmen, son 200 yll içerisinde yedi kat artarak yedi milyara ulaşmıştır (UNFPA, 2017). Türkiye'de ise 1960'lı yıllarda yaklaşık 27 milyon olan nüfus, günümüz itibariyle 80 milyonu geçerek 80 milyon 810 bin 525 kişiye ulaşmıştır (TÜİK, 2017). Bu nüfus artışıyla beraber dünya üzerinde giderek artan su ve besin ihtiyacına bağlı olarak gereksinim duyulan bu maddelerinin ekonomik değeri artacaktır.

Dünyanın birçok ülkesinde ve Türkiye'de toprak, su, orman ve hava gibi doğal kaynaklar; hatalı ve plansız arazi kullanımı, yüksek nüfus artışı, bu doğal kaynaklara yönelik çok yönlü istekler, kurumsal destek ve yönlendirmelerin yetersizliği ya da olmayışı gibi nedenlerle tehdit altında bulunmaktadır (Salvati ve ark, 2016). Bu nedenle arazi toplulaştırması ile tarım bölgeleri veya doğal yaşam ortamlarındaki temiz su rejimleri için önemli olan bazı toprak türlerinin konumu; korunmalı ve güçlendirmelidir (Moravcová ve ark, 2017).

$\mathrm{Bu}$ nedenle çoğu Avrupa ülkesi arazilerin bölünmesini azaltmak için sayısız arazi toplulaştırması ve sayısız reformlar uygulamıştır (Hiironen ve Riekkinen, 2016). Ülkemizde de bu konuyla ilgili 1961 yılından bu yana birçok çalışma yapılmaktadır. Bunlardan ilki ise Konya iline bağlı bulunan Karkın köyünde başlatılmıştır (Cay ve ark, 2010). 1961 ile 2014 yılları arasında ise 4.982 .785 hektar alan üzerinde toplulaştırma çalışmaları yapılmıştır (TRGM, 2017). Yine TÜİK (2014) verilerine göre Türkiye'deki toplam tarım alanları 38.558 hektar olarak görülmektedir.

Toplulaștırma sonrası analizler yapıldığı zaman somut olarak göze çarpabilen ilk konu sayılarla ifade edilebilen ekonomidir (Van Huylenbroeck ve ark, 1996). Tarım çalışmalarının ülke ekonomisine dönüşü \%9 olarak karşımıza çıkarken, maliyetler de göz önüne alındığında bu rakam \%8 olarak karşımıza çıkmaktadır (Van den Noort, 1987). Sklenicka ve ark (2009) yaptıkları çalışmada toplulaştırma sahasında parça sayısının artmasına bağlı olarak maliyetin de arttığını ileri sürmüşlerdir. Kumbasaroğlu ve Dağdemir (2007) Erzurum'da yaptığı çalışmada parçalı arazilerin ekonomiye etkileriyle ilgili yaptıkları çalışmada GSH değerlerine göre bitkisel üretim değerinin 1618,3 TL, hayvansal üretim değeri 2834,8 TL, diğer tarımsal gelirlerin 270,8 TL, demirbaş kıymet artışının 1114,8 TL ve GSH 5838,7 TL olduğunu tespit etmişlerdir. Bölgesel ekonomi üzerindeki arazi toplulaștırma projesinin yatırımının büyük bir katkısı, bölgesel GSYİH' nın uygulama aşamasında \% 16.05 oranında arttığl, fayda aşamasında ise, \% 10.16 oranında arttığ veriden kolayca tespit edilebilir (Jin ve ark, 2016).

Bu nedenle ülkemiz bașta olmak üzere dünya da öncelikli olarak arazi toplulaştırma projelerinin ekonomik analizinin yapılarak ekonomik verimliliğinin artırılması, bunu yaparken de doğal yaşamın sürdürülebilirliğini bozmadan yapılması önem arz etmektedir.

\section{YÖNTEM}

Proje sahası olarak ise hali hazırda arazi toplulaştırma çalışmaları yapılmış olan Konya İlinde yer alan Üçhüyük Mahallesi seçilmiştir. Analiz yapılırken proje sahasına gidilerek proje sahası ile ilgili incelemelerde bulunulmuş ve çiftçi görüşlerine başvurulmuştur. Bu sayede teorikte bulunan bazı bilgilerin pratikteki karşılıkları ve sonuçları görülmüştür.

\subsection{Uygulama Alanı Açıklamaları}

Üçhüyük Mahallesi bağlı olduğu Çumra ilçe merkezine 22 kilometre mesafe uzaklıkta olup Konya şehir merkezine mesafesi ise yaklaşı 66 kilometredir. Ayrica Mahallenin rakımı da 1002 metredir (Ertunç ve ark, 2018).

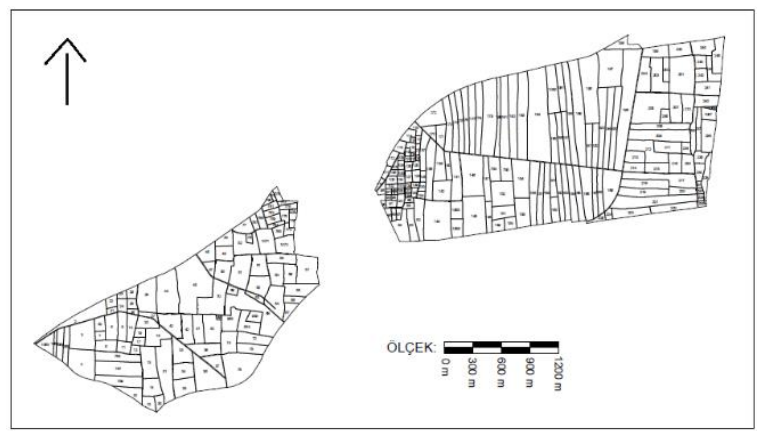

Şekil 1. Kadastro Durumu

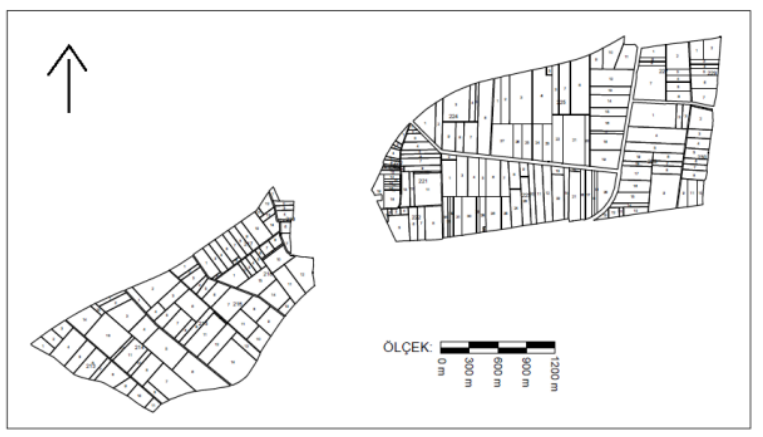

Şekil 2. Arazi Toplulaştırma Durumu

Üçhüyük Mahallesi toplulaştırma öncesi mülkiyet yapısı şekil 1'de gösterilmektedir. Toplulaştırma sonrası mülkiyet yapısı ise şekil 2'de görülmektedir. Toplulaştırma öncesi bulunan mevcut durumda 274 işletmeye ait 265 parsel bulunmaktadır. Toplulaştırmaya giren toplam alan 875,69 hektardır. Toplulaştırma sonrası oluşan yeni durumda yine 274 işletme ait bulunan 243 yeni parsel oluşmuştur. Toplulaştırma sonrası oluşan yeni durumda toplam alan 836,16 hektardır.

Ayrıca bölgede yetiştirilen geniş bir ürün yelpazesi olmasına rağmen mevcut tarlaların \%40' 1 hububata, \%20 si şeker pancarına, \%25 i mısıra ve 
geriye kalan \%15'lik tarla ise diğer ürünlere ayrılmaktadır.

\section{BULGULAR}

Toplulaştırma çalışmalarının işletmelere dayalı ekonomik analizinin yapılması toplulaştırmanın çiftçiler üzerindeki etkilerinin belirlenebilmesi açısından önemlidir. Bu hesaplama gayri safi üretim değeri, gayri safi hasıla, işletme masrafları, saf hasıla, tarımsal gelir ve mutlak kar baz alınarak hesaplanmiştır.

Bunun için öncelikle işletmeler 3 gruba ayrılmıştır. 1. Grup 0-50 dönüm, 2. Grup 50-100 dönüm, 3. Grup $100<$ olacak şekilde sınırları belirlenmiştir.

Tablo 1'de toplulaştırma öncesinde 3 grubun mevcut işletme sayları ve toplam işletme alanları görülmektedir.

Tablo 1. Toplulaștırma Öncesi İșletme Verileri

\begin{tabular}{|l|l|l|l|l|l|}
\hline \multicolumn{5}{|l|}{ Toplulaştırma Öncesinde } \\
\hline \multirow{2}{*}{ Gruplar } & $\begin{array}{l}\text { İşletme } \\
\text { Büyüklüğü } \\
\text { (da) }\end{array}$ & \multicolumn{3}{|l|}{ İşletme Sayısı } & \multicolumn{2}{l|}{$\begin{array}{l}\text { Toplam İşletme } \\
\text { Alanı }\end{array}$} \\
\cline { 3 - 6 } & (Adet) & $(\%)$ & Da & $(\%)$ \\
\hline 1.Grup & $0-50$ & 216 & 79 & 3.427 & 39 \\
\hline 2.Grup & $50-100$ & 38 & 14 & 2.588 & 30 \\
\hline 3.Grup & $100<$ & 20 & 7 & 2.742 & 31 \\
\hline & Toplam & 274 & 100 & 8.757 & 100 \\
\hline
\end{tabular}

Tablo 2'de ise toplulaştırma sonrasında 3 grubun mevcut işletme sayıları ve toplam işletme alanları görülmektedir.

Tablo 1 ve Tablo 2'de bulunan mevcut verilerden yola çıkarak 3 gruba ayrılan işletmelerin yukarıda belirtilen kriterlere göre ekonomik analizi gerçekleştirilmiştir. $\mathrm{Bu}$ sayede toplulaştırmanın çiftçiler üzerine ekonomik analizi yapılmıştır.

Tablo 2. Toplulaștırma Sonrası İșletme Verileri

\begin{tabular}{|l|l|l|l|l|l|}
\hline \multicolumn{2}{|l|}{ Toplulaştırma Sonrasında } \\
\hline \multirow{2}{*}{ Gruplar } & $\begin{array}{l}\text { İşletme } \\
\text { Büyüklüğü } \\
\text { (da) }\end{array}$ & \multicolumn{2}{l|}{ İşletme Sayısı } & \multicolumn{3}{l|}{\begin{tabular}{l}
\multicolumn{2}{l|}{ Toplam İşletme } \\
Alanı
\end{tabular}} \\
\cline { 3 - 6 } & (Adet) & $(\%)$ & Da & $(\%)$ \\
\hline 1.Grup & $0-50$ & 218 & 80 & 3.416 & 41 \\
\hline 2.Grup & $50-100$ & 38 & 14 & 2.617 & 31 \\
\hline 3.Grup & $100<$ & 18 & 7 & 2.329 & 28 \\
\hline & Toplam & 274 & 100 & 8.362 & 100 \\
\hline
\end{tabular}

\subsection{Gayri Safi Üretim Değeri}

Gayri safi üretim değerinin bulunabilmesi için öncelikle toplulaştırma öncesi ve toplulaştırma sonrası değerler ayrı ayrı hesaplanmıştır.

Tablo 3 ve Tablo 4'deki değerler proje sahasında yetişen mahsullerin ekonomik değerlerine göre hesaplanmıştır.

Tablo 3. Toplulaştırma Öncesi Tarımsal Üretim Değerleri

\begin{tabular}{|l|l|l|l|}
\hline \multicolumn{3}{|l|}{ Toplulaştırma Öncesinde } & \multicolumn{2}{l|}{ Toplam İşletme Alanı } & $\begin{array}{l}\text { Tarımsal } \\
\text { Üretim } \\
\text { Değeri }\end{array}$ \\
\hline \multirow{2}{*}{ Gruplar } & \multicolumn{2}{|l|}{} & TL \\
\cline { 2 - 4 } & Da & $(\%)$ & 3.558 .823 \\
\hline 1.Grup & 3.427 & 39 & 2.687 .010 \\
\hline 2.Grup & 2.588 & 30 & 2.847 .122 \\
\hline 3.Grup & 2.742 & 31 & 3.030 .985 \\
\hline Ortalama & 2.919 & &
\end{tabular}

Toplam tarımsal üretim değeri üzerinden 1 . Grup, 2. Grup ve 3.Grup hesaplanmıștır. Ardından bu değerlerin ortalamaları alınmıştır. $\mathrm{Bu}$ durumda tarımsal üretim değeri en çok 1.Grup da var iken en az 3.Grup ta bulunmaktadır.

Tablo 4'e bakıldığı zaman gayri safi üretim değerine etki eden 2 etken görülmektedir. Bunlardan birincisi tarımsal üretim değeri diğeri ise kullanılmayan parsel sınırındaki alan kaynaklı gelir artışı olarak karşımıza çıkmaktadır. Toplulaştırma sonrasındaki mevcut durumda ise toplam üretim değeri 1. Grupta en fazla iken 3. Grupta en az olarak karşımıza çıkmaktadır.

Tablo 4. Toplulaştırma Sonrası Tarımsal Üretim Değerleri

\begin{tabular}{|c|c|c|c|c|c|}
\hline \multicolumn{6}{|c|}{ Toplulaştırma Sonrasında } \\
\hline \multirow[t]{2}{*}{ Gruplar } & \multicolumn{2}{|c|}{$\begin{array}{l}\text { Toplam } \\
\text { İşletme } \\
\text { Alanı }\end{array}$} & \multirow{2}{*}{\begin{tabular}{|l} 
Tarımsal \\
Üretim \\
Değeri \\
TL
\end{tabular}} & \multirow{2}{*}{$\begin{array}{l}\text { Kullanılama } \\
\text { yan Parsel } \\
\text { Sınırındaki } \\
\text { Alan } \\
\text { Kaynaklı } \\
\text { Gelir Artışı } \\
\\
\text { TL }\end{array}$} & \multirow{2}{*}{$\begin{array}{l}\text { Toplam } \\
\text { Üretim } \\
\text { Değeri } \\
\text { TL }\end{array}$} \\
\hline & $\mathrm{Da}$ & $\%$ & & & \\
\hline 1.Grup & 3.416 & 41 & 4.256 .817 & 3.299 & 4.260 .115 \\
\hline 2.Grup & 2.617 & 31 & 3.260 .321 & 2.526 & 3.262 .847 \\
\hline 3.Grup & 2.329 & 28 & 2.901 .829 & 2.249 & 2.904 .078 \\
\hline Ortalama & 2.787 & & 3.472 .989 & 2.691 & 3.475 .680 \\
\hline
\end{tabular}


Tablo 5'e bakıldığı zaman toplulaştırma öncesi gayri safi üretim değerleri, toplulaştırma sonrası gayri safi üretim değerleri ve bu ikisinin farkı görülmektedir. Değerlere bakıldığında yine 1. Grupta en fazla artışın olduğu görülmektedir.

Tablo 5. Toplulaștırma Sonrası ve Öncesi Tarımsal Üretim Değerleri Farkı

\begin{tabular}{|l|l|l|l|}
\hline \multirow{4}{*}{ Gruplar } & $\begin{array}{l}\text { Toplulaştırma } \\
\text { Öncesi }\end{array}$ & $\begin{array}{l}\text { Toplulaştırma } \\
\text { Sonrası }\end{array}$ & TS-TÖ \\
\cline { 2 - 4 } & $\begin{array}{l}\text { Tarımsal } \\
\text { Üretim Değeri }\end{array}$ & $\begin{array}{l}\text { Tarımsal } \\
\text { Üretim Değeri }\end{array}$ & $\begin{array}{l}\text { Tarımsal } \\
\text { Üretim } \\
\text { Değeri }\end{array}$ \\
\cline { 2 - 4 } & TL & TL & TL \\
\hline 1.Grup & 3.558 .823 & 4.260 .115 & 701.293 \\
\hline 2.Grup & 2.687 .010 & 3.262 .847 & 575.837 \\
\hline 3.Grup & 2.847 .122 & 2.904 .078 & 56.956 \\
\hline Ortalama & 3.030 .985 & 3.475 .680 & 444.695 \\
\hline
\end{tabular}

\subsection{Gayri Safi Hasıla}

Gayri safi hasıla gayri safi üretim değerine konut kira bedelinin eklenmesi ile bulunmaktadır (Karl, 2018). Bu nedenle gayri safi üretim değerine konut kira değeri eklenerek bulunmuştur.

Tablo 6'da toplulaştırma öncesinde 3 grubun gayri safi hasıla değerleri bulunmuştur. Arazi kira bedeli hesaplanırken 1 dekar arazi kirası buğday için 32 kilogram, pancar için 1000 kilogram baz alınmak suretiyle hesaplanmıştır. Bu hesaplama için her grup için ayrı ayrı hesaplanan gayri safi üretim değerleri ile yine aynı şekilde her bir grup için ayrı ayrı hesaplanan konut kira değerlerinin toplanması ile gayri safi hasıla değerlerine ulaşılmıştır.

Tablo 6. Toplulaştırma Öncesi Gayri Safi Hasıla Değerleri

\begin{tabular}{|c|c|c|c|}
\hline \multirow{3}{*}{ Gruplar } & \multicolumn{3}{|c|}{ Toplulaştırma Öncesi } \\
\hline & $\begin{array}{ll}\text { Gayri } & \text { Safi } \\
\text { Üretim } & \\
\text { Değeri } & \end{array}$ & $\begin{array}{ll}\text { Arazi } & \text { Kira } \\
\text { Bedeli } & \end{array}$ & $\begin{array}{ll}\text { Gayri } & \text { Safi } \\
\text { Hasıla } & \end{array}$ \\
\hline & $\mathrm{TL}$ & $\mathrm{TL}$ & $\mathrm{TL}$ \\
\hline 1.Grup & 3.558 .823 & 685.460 & 4.244 .282 \\
\hline 2.Grup & 2.687.010 & 517.542 & 3.204 .552 \\
\hline 3.Grup & 2.847.122 & 548.380 & 3.395 .502 \\
\hline Ortalama & 3.030 .985 & 583.794 & 3.614 .779 \\
\hline
\end{tabular}

Yine Tablo 6'da görüldüğü gibi 1. Grubun gayri safi hasıla değeri en fazla iken 2. Grubun gayri safi hasıla değeri en az olarak karşımıza çıkmaktadır.
Grup 2 ve Grup 3'ün gayri safi hasıla değerleri ortalama gayri safi hasıla değerinin altında kalmaktadır.

Tablo 7'de ise toplulaştırma sonrası gayri safi hasıla değerleri görülmektedir. Toplulaştırma sonrasında da yine toplulaştırma öncesi gayri safi hasıla değerlerinde olduğu gibi 1 . Grup en fazla değere sahiptir.

Tablo 7. Toplulaştırma Sonrası Gayri Safi Hasıla Değerleri

\begin{tabular}{|c|c|c|c|}
\hline \multirow{3}{*}{ Gruplar } & \multicolumn{3}{|c|}{ Toplulaștırma Sonrası } \\
\hline & $\begin{array}{ll}\text { Gayri } & \text { Safi } \\
\text { Üretim } & \\
\text { Değeri } & \end{array}$ & $\begin{array}{ll}\text { Arazi } & \text { Kira } \\
\text { Bedeli } & \end{array}$ & $\begin{array}{ll}\text { Gayri } & \text { Safi } \\
\text { Hasıla } & \end{array}$ \\
\hline & $\mathrm{TL}$ & $\mathrm{TL}$ & $\mathrm{TL}$ \\
\hline 1.Grup & 4.260 .115 & 785.740 & 5.045 .856 \\
\hline 2.Grup & 3.262 .847 & 601.802 & 3.864 .649 \\
\hline 3.Grup & 2.904 .078 & 535.631 & 3.439 .709 \\
\hline Ortalama & 3.475 .680 & 641.058 & 4.116 .738 \\
\hline
\end{tabular}

Tablo 8'e bakıldığı zaman 3 Grup için gayri safi hasıla değerlerinin arazi toplulaştırma projesi öncesi ve sonrası arasındaki farklar görülmektedir. Aradaki farka bakıldığı zaman 1. Grup en fazla farka sahiptir. Ancak en az farka sahip grup ise 3. Grup olarak karşımıza çıkmaktadır.

Tablo 8. Toplulaştırma Sonrası ve Toplulaştırma Öncesi Gayri Safi Hasıla Değerleri Farkı

\begin{tabular}{|c|c|c|c|}
\hline \multirow{3}{*}{ Gruplar } & $\begin{array}{l}\text { Toplulaştırma } \\
\text { Öncesi }\end{array}$ & $\begin{array}{l}\text { Toplulaştırma } \\
\text { Sonrası }\end{array}$ & TS-TÖ \\
\hline & $\begin{array}{ll}\text { Gayri } & \text { Safi } \\
\text { Hasıla } & \end{array}$ & $\begin{array}{ll}\text { Gayri } & \text { Safi } \\
\text { Hasıla } & \end{array}$ & $\begin{array}{l}\text { Gayri Safi } \\
\text { Hasıla }\end{array}$ \\
\hline & $\mathrm{TL}$ & TL & $\mathrm{TL}$ \\
\hline 1.Grup & 4.244 .282 & 5.045 .856 & 801.573 \\
\hline 2.Grup & 3.204 .552 & 3.864 .649 & 660.097 \\
\hline 3.Grup & 3.395 .502 & 3.439.709 & 44.207 \\
\hline Ortalama & 3.614.779 & 4.116 .738 & 501.959 \\
\hline
\end{tabular}

\section{2. İşletme Masrafları}

İşletme masraflarının hesaplanması işletmelerin karlarının hesaplanabilmesi açısından önemlidir. İşletme masrafları mazot, sulama ve mevsimlik işçi masrafları olmak üzere üç kalemde incelenmiştir. 
Bunlardan ilki olan mazot masraflarıdır. Mazot masrafları hesaplanırken öncelikle proje sahasında çiftçilerin tarım için kat ettiği toplam mesafe hesaplanmıştır. Ardından mesafenin kat edilebilmesi için gereken mazot masrafı hesaplanarak ortalama işletme masrafi hesaplanmıştır.

Bir diğer masraf unsuru ise sulama masrafları olarak karşımıza çıkmaktadır. Sulama masrafları hesaplanırken proje sahasında yetiștirilen her ürünün ihtiyacı olan su miktarına göre hesaplama yapılmıştır.

Son olarak mevsimlik ișçi maliyetleri hesaplanırken yine her dekar $\left(1000 \mathrm{~m}^{2}\right)$ için $100 \mathrm{TL}$ baz alınarak hesaplamalar yapılmıştır.

Tablo 9'a bakıldığı zaman mazot hanesinde 1 . Grup diğer 2 gruba nazaran oldukça yüksek bir değer almaktadır. Bunun nedeni 1. Grupta bulunan işletme sayısının diğer gruplardan fazla olması olarak gösterilebilir. Ancak sulama ve mevsimlik işçi giderlerinde de 1. Grup en fazla işletme masrafina sahip olan gruptur. 2. ve 3. Gruplara bakıldığı zaman ise mazotta 2. Grup, sulamada 3.Grup ve yine mevsimlik iş̧̧i masraflarında 3. Grubun daha fazla maliyete sahip olduğu görülmektedir.

Tablo 9. Toplulaștırma Öncesi İșletme Giderleri

\begin{tabular}{|c|c|c|c|c|}
\hline \multirow{3}{*}{ Gruplar } & \multicolumn{4}{|c|}{ Toplulaştırma Öncesi } \\
\hline & Mazot & Sulama & $\begin{array}{l}\text { Mevsimlik } \\
\text { İşçi }\end{array}$ & Toplam \\
\hline & $\mathrm{TL}$ & $\mathrm{TL}$ & $\mathrm{TL}$ & $\mathrm{TL}$ \\
\hline 1.Grup & 41.862 & 33.245 & 342.730 & 417.837 \\
\hline 2.Grup & 7.645 & 25.101 & 258.771 & 291.517 \\
\hline 3.Grup & 4.014 & 26.595 & 274.190 & 304.800 \\
\hline Ortalama & 17.841 & 28.314 & 291.897 & 338.051 \\
\hline
\end{tabular}

Tablo 10'a bakıldığı zaman ise yine Tablo 9'a benzer bir tablo karşımıza çıkmaktadır. Ancak grupların maliyet oranlarında bir düşüş olduğu görülmektedir.
Tablo 10. Toplulaștırma Sonrası İșletme Giderleri

\begin{tabular}{|c|c|c|c|c|}
\hline \multirow{3}{*}{ Gruplar } & \multicolumn{4}{|c|}{ Toplulaştırma Sonrası } \\
\hline & Mazot & Sulama & $\begin{array}{l}\text { Mevsimlik } \\
\text { İşçi }\end{array}$ & Toplam \\
\hline & TL & TL & TL & $\mathrm{TL}$ \\
\hline 1.Grup & 32.554 & 26.510 & 341.626 & 400.690 \\
\hline 2.Grup & 5.719 & 20.304 & 261.653 & 287.676 \\
\hline 3.Grup & 2.786 & 18.072 & 232.883 & 253.741 \\
\hline Ortalama & 13.686 & 21.629 & 278.721 & 314.036 \\
\hline
\end{tabular}

Toplulaştırma öncesi ve toplulaştırma sonrası işletme masraflarının daha iyi anlaşılabilmesi için toplulaştırma öncesi toplam işletme masrafları ile toplulaştırma sonrası toplam işletme masraflarının farkı alınmıştır. $\mathrm{Bu}$ değerler Tablo 11 'de görülmektedir. Toplulaştırma sonucunda işletme masraflarındaki en büyük tasarruf 3. Grupta iken en az tasarruf oranı ise 2. Grupta görülmektedir. Buradan yola çıkılarak büyük arazi sahiplerinin daha çok tasarruf yaptıkları görülmektedir.

Tablo 11. Toplulaştırma Sonrası ve Toplulaştırma Öncesi İşletme Giderleri Farkı

\begin{tabular}{|l|l|l|l|}
\hline \multirow{2}{*}{ Gruplar } & $\begin{array}{l}\text { Toplulaştırma } \\
\text { Öncesi }\end{array}$ & $\begin{array}{l}\text { Toplulaştırma } \\
\text { Sonrası }\end{array}$ & TÖ-TS \\
\cline { 2 - 4 } & $\begin{array}{l}\text { İşletme } \\
\text { Masrafları }\end{array}$ & $\begin{array}{l}\text { İşletme } \\
\text { Masrafları }\end{array}$ & $\begin{array}{l}\text { İşletme } \\
\text { Masrafları }\end{array}$ \\
\cline { 2 - 4 } & TL & TL & TL \\
\hline 1.Grup & 417.837 & 400.690 & 17.147 \\
\hline 2.Grup & 291.517 & 287.676 & 3.841 \\
\hline 3.Grup & 304.800 & 253.741 & 51.059 \\
\hline Ortalama & 338.051 & 314.036 & 24.015 \\
\hline
\end{tabular}

\subsection{Saf Hasıla}

Saf hasıla işletmeye yatırılan aktif sermayenin rantı olduğundan önem arz etmektedir. Saf hasıla değeri, gayri safi hasıladan işletme masraflarının çıkarılması ile bulunmuştur (Karlı, 2018). 
Tablo 12'de toplulaştırma öncesindeki gayri safi hasıla değerlerinden işletme masrafları çıkarılarak saf hasıla elde edilmiștir. En yüksek saf hasıla değerine 1.Grup sahiptir.

Tablo 12. Toplulaștırma Öncesi Saf Hasıla Değerleri

\begin{tabular}{|l|l|l|l|}
\hline \multirow{2}{*}{ Gruplar } & \multicolumn{3}{|l|}{ Toplulaştırma Öncesi } \\
\cline { 2 - 4 } & $\begin{array}{l}\text { Gayri Safi } \\
\text { Hasıla }\end{array}$ & $\begin{array}{l}\text { İșletme } \\
\text { Masrafları }\end{array}$ & Saf Hasıla \\
\cline { 2 - 4 } & TL & TL & TL \\
\hline 1.Grup & 4.244 .282 & 417.837 & 3.826 .445 \\
\hline 2.Grup & 3.204 .552 & 291.517 & 2.913 .035 \\
\hline 3.Grup & 3.395 .502 & 304.800 & 3.090 .702 \\
\hline Ortalama & 3.614 .779 & 338.051 & 3.276 .728 \\
\hline
\end{tabular}

Tablo 13'de toplulaştırma sonrasındaki saf hasıla değerleri görülmektedir. Yine bu değerler hesaplanırken toplulaştırma sonrasındaki gayri safi hasıla değerlerinden işletme masrafları çıkarılarak bulunmuștur. Toplulaștırma sonrasında en yüksek saf hasıla değerine 1.Grup sahipken, en düşük saf hasıla değerine ise 3.Grup sahiptir.

Tablo 13. Toplulaștırma Sonrası Saf Hasıla Değerleri

\begin{tabular}{|l|l|l|l|}
\hline \multirow{2}{*}{ Gruplar } & \multicolumn{3}{|l|}{ Toplulaştırma Sonrası } \\
\cline { 2 - 4 } & $\begin{array}{l}\text { Gayri Safi } \\
\text { Hasıla }\end{array}$ & $\begin{array}{l}\text { İşletme } \\
\text { Masrafları }\end{array}$ & Saf Hasıla \\
\cline { 2 - 4 } & TL & TL & TL \\
\hline 1.Grup & 5.045 .856 & 400.690 & 4.645 .165 \\
\hline 2.Grup & 3.864 .649 & 287.676 & 3.576 .973 \\
\hline 3.Grup & 3.439 .709 & 253.741 & 3.185 .968 \\
\hline Ortalama & 4.116 .738 & 314.036 & 3.802 .702 \\
\hline
\end{tabular}

Tablo 14'de ise toplulaștırma öncesi ve toplulaştırma sonrasındaki saf hasıla değerleri karşılaştırılmıştır. Tabloda görüldüğü üzere toplulaştırma sonrasında işletmelerin toplulaştırma öncesine göre saf hasıla artmaktadır. Ancak en büyük artış 1. Grupta iken en düşük artış 3. Grupta görülmektedir.
Tablo 14. Toplulaştırma Sonrası ve Öncesi Saf Hasıla Değerleri Farkı

\begin{tabular}{|l|l|l|l|}
\hline \multirow{2}{*}{ Gruplar } & $\begin{array}{l}\text { Toplulaştırma } \\
\text { Öncesi }\end{array}$ & $\begin{array}{l}\text { Toplulaştırma } \\
\text { Sonrası }\end{array}$ & TS-TÖ \\
\cline { 2 - 4 } & Saf Hasıla & Saf Hasıla & Saf Hasıla \\
\cline { 2 - 4 } & TL & TL & TL \\
\hline 1.Grup & 3.826 .445 & 4.645 .165 & 818.720 \\
\hline 2.Grup & 2.913 .035 & 3.576 .973 & 663.938 \\
\hline 3.Grup & 3.090 .702 & 3.185 .968 & 95.266 \\
\hline Ortalama & 3.276 .728 & 3.802 .702 & 525.975 \\
\hline
\end{tabular}

\subsection{Mutlak Net Kar}

Mutlak kar işletmelerin gayri safi üretim değerlerinden işletme masraflarının çıarılmasıyla elde edilen değerdir. Bu kar kısaca çiftçilerin elinde kalan kar olarak da yorumlanabilir.

Tablo 15'de toplulaştırma öncesi her bir grup için mutlak kar değerleri görülmektedir. Bunun için her bir grup için gayri safi üretim değerinden işletme masrafları çıkarılmıştır. Sonuçlara bakıldığında en yüksek mutlak kar 1. Gruba ait iken en düşük mutlak kar 2. Gruba aittir.

Tablo 15. Toplulaştırma Öncesi Mutlak Net Kar

\begin{tabular}{|l|l|l|l|}
\hline \multirow{4}{*}{ Gruplar } & \multicolumn{3}{|l|}{ Toplulaştırma Öncesi } \\
\cline { 2 - 4 } & $\begin{array}{l}\text { Gayri Safi } \\
\text { Üretim } \\
\text { Değeri }\end{array}$ & $\begin{array}{l}\text { İşletme } \\
\text { Masrafları }\end{array}$ & Mutlak Kar \\
\cline { 2 - 4 } & TL & TL & TL \\
\hline 1.Grup & 3.558 .823 & 417.837 & 3.140 .985 \\
\hline 2.Grup & 2.687 .010 & 291.517 & 2.395 .494 \\
\hline 3.Grup & 2.847 .122 & 304.800 & 2.542 .322 \\
\hline Ortalama & 3.030 .985 & 338.051 & 2.692 .934 \\
\hline
\end{tabular}

Tablo 16 'da ise toplulaştırma sonrası her bir grup için mutlak kar değerleri görülmektedir. Bunun için her bir grup için gayri safi üretim değerinden işletme masrafları çıkarılmıştır. Sonuçlara bakıldığında en yüksek mutlak kar 1. Gruba ait iken en düşük mutlak kar 3. Gruba aittir. 
Tablo 16. Toplulaștırma Sonrası Mutlak Net Kar

\begin{tabular}{|l|l|l|l|}
\hline \multirow{4}{*}{ Gruplar } & \multicolumn{3}{|c|}{ Toplulaştırma Sonrası } \\
\cline { 2 - 4 } & $\begin{array}{l}\text { Gayri Safi } \\
\text { Üretim } \\
\text { Değeri }\end{array}$ & $\begin{array}{l}\text { İşletme } \\
\text { Masrafları }\end{array}$ & Mutlak Kar \\
\cline { 2 - 4 } & TL & TL & TL \\
\hline 1.Grup & 4.260 .115 & 400.690 & 3.859 .425 \\
\hline 2.Grup & 3.262 .847 & 287.676 & 2.975 .171 \\
\hline 3.Grup & 2.904 .078 & 253.741 & 2.650 .337 \\
\hline Ortalama & 3.475 .680 & 314.036 & 3.161 .644 \\
\hline
\end{tabular}

Tablo 17'ye bakıldığı zaman toplulaştırma öncesi mutlak kar ile toplulaştırma sonrasındaki mutlak karın karşılaştırılması görülmektedir. Toplulaştırma sonrasındaki mutlak karın toplulaştırma öncesindeki mutlak kara göre arttığ görülmektedir. $\mathrm{Bu}$ artış ortalama 468.710,49 TL olarak karşımıza çıkmaktadır. Ayrıca en büyük mutlak kar 1. Gruba ait iken en düşük mutlak kar 3. Gruba aittir.

Tablo 17. Toplulaştırma Öncesi ve Sonrası Mutlak Net Kar Farkı

\begin{tabular}{|l|l|l|l|}
\hline \multirow{2}{*}{ Gruplar } & $\begin{array}{l}\text { Toplulaştırma } \\
\text { Öncesi }\end{array}$ & $\begin{array}{l}\text { Toplulaştırma } \\
\text { Sonrası }\end{array}$ & TS-TÖ \\
\cline { 2 - 4 } & Mutlak Kar & Mutlak Kar & Mutlak Kar \\
\cline { 2 - 4 } & TL & TL & TL \\
\hline 1.Grup & 3.140 .985 & 3.859 .425 & 718.440 \\
\hline 2.Grup & 2.395 .494 & 2.975 .171 & 579.677 \\
\hline 3.Grup & 2.542 .322 & 2.650 .337 & 108.014 \\
\hline Ortalama & 2.692 .934 & 3.161 .644 & 468.710 \\
\hline
\end{tabular}

\subsection{Tartışma}

Toplulaştırmanın işletmelere etkileri değerlendirildiği zaman işletme başına karda yine en fazla 3. Grup işletmeler varken 2. Grup işletmeler 2. sırada, 1. Grup işletmeler ise son sıradadır. 100 dönüm ve üzeri alana sahip işletmelerde meydana gelen 20.125 TL kar son derece önemli bir kardır. Bu değer bile toplulaştırma projelerinin ekonomik karının ne kadar önemli olduğunu bir kez daha gözler önüne sermektedir.

Tablo 18'e bakıldığı zaman toplulaştırma öncesi ve toplulaştırma sonrasında işletme başına mutlak karlar görülmektedir. Tablo 18 incelendiğinde mutlak karda 1. Grup en fazla değer sahip olsa da işletme başına karda 3. Grup en fazla değere sahiptir.
Ayrıca 1. Grup işletmeler ise en az mutlak kara sahip işletmeler olarak karşımıza çıkmaktadır. Bu durum büyük araziye sahip ișletmelerin mutlak karlarının daha fazla olduğunu göstermektedir.

Tablo 18. Toplulaștırma Sonrası ve Toplulaştırma Öncesi Mutlak Net Kar Farkı

\begin{tabular}{|c|c|c|c|}
\hline \multicolumn{4}{|c|}{ Toplulaștırma Öncesi } \\
\hline Gruplar & 1.Grup & 2.Grup & 3.Grup \\
\hline Mutlak Kar & 3.140 .985 & 2.395 .494 & 2.542 .322 \\
\hline $\begin{array}{l}\text { İşletme } \\
\text { Sayıları }\end{array}$ & 216 & 38 & 20 \\
\hline $\begin{array}{l}\text { İşletme } \\
\text { Başına Kar }\end{array}$ & 14.542 & 63.039 & 127.116 \\
\hline \multicolumn{4}{|c|}{ Toplulaştırma Sonrası } \\
\hline Gruplar & 1.Grup & 2.Grup & 3.Grup \\
\hline Mutlak Kar & 3.859 .425 & 2.975 .171 & 2.650 .337 \\
\hline $\begin{array}{l}\text { İşletme } \\
\text { Sayıları }\end{array}$ & 218 & 38 & 18 \\
\hline $\begin{array}{l}\text { İşletme } \\
\text { Başına Kar }\end{array}$ & 17.704 & 78.294 & 147.241 \\
\hline $\begin{array}{l}\text { İşletme } \\
\text { Başına Kar } \\
\text { Farkı }\end{array}$ & 3.162 & 15.255 & 20.125 \\
\hline
\end{tabular}

Karlı (2018) çalışmasında tarım işletmelerinin ekonomik analizi yapılmıştır. Parsel büyüklüğü bazında 3 gruba ayırdıkları işletmelerden en büyük gelirin büyük parsellere sahip ișletmelerin elde ettiği sonucuna ulaşmışlardır. Ayrıca 65 işletme üzerinde yaptıkları çalışmalarda ise ortalama işletme karının 28.264,94 TL olduğunu belirlemişlerdir. Bu sonuçlar karşılaştırıldığında farklı proje sahalarında benzer proje ișletme karlarının bulunduğu söylenebilir.

\section{SONUÇ}

Toplulaştırmanın çiftçiler üzerindeki etkileri incelenerek toplulaştırma projelerinin çiftçi grupları üzerindeki analizleri yapılmıştır. Proje sahasındaki işletmeler 0-50 dekar, 50-100 dekar ve 100 dekar üzeri olacak şekilde 3 gruba ayrılmış ve gruplar üzerinden analizler yapılmıștır. Toplulaștırma öncesi ile sonrası işletme başına kar kıyaslandığında, 
toplulaştırma sonrasında 100 dekar ve üzeri işletmeler 20.124,82 TL, 50-100 dekar işletmeler 15.254,67 TL, 0-50 dekar ișletmeler ise 3.162,19 TL'lik kar elde etmişlerdir.

$\mathrm{Bu}$ sonuçlara bakarak büyük toprak alanına sahip işletmelerin daha fazla ekonomik kazanç elde ettiği, daha küçük alana sahip işletmelerin daha az ekonomik kazanç elde etmiştir. Ekonomik kazançları artan arazi sahipleri daha rekabetçi hale gelmişlerdir. $\mathrm{Bu}$ durum daha büyük araziler hedefleyen arazi toplulaștırma projelerinin ne kadar doğru yatırımlar olduğunu bir kez daha göstermektedir.

\section{KAYNAKÇA}

Cay T, Ayten T, Iscan F, 2010. Effects of different land reallocation models on the success of land consolidation projects: Social and economic approaches. Land Use Policy, 27, 2, 262-9.

Ertunç E, Çay T, Haklı H, 2018. Modeling of reallocation in land consolidation with a hybrid method. Land Use Policy, 76, 754-61.

Hiironen J, Riekkinen K, 2016. Agricultural impacts and profitability of land consolidations. Land Use Policy, 55, 309-17.

Jin XB, Xu XX, Xiang XM, Bai Q, Zhou YK, 2016. System-dynamic analysis on socio-economic impacts of land consolidation in China. Habitat Int, 56, 166-75.

Karlı, 2018. Isparta İlinde Arazi Toplulaştırması Yapılan Alanlardaki Tarım İşletmelerinin SosyoEkonomik Analizi. MKÜ Dergisi, 23, 1, 106-14.

Kumbasaroğlu H, Dağdemir V, 2007. Erzurum Merkez ilçede tarım arazilerinde parçalılık durumuna göre tarım işletmelerinin ekonomik analizi. Atatürk Üniversitesi Ziraat Fakültesi Dergisi, 38, 1, 49-58.

Moravcová J, Koupilová M, Pavlíček T, Zemek F, Kvítek T, Pečenka J, 2017. Analysis of land consolidation projects and their impact on land use change, landscape structure, and agricultural land resource protection: case studies of Pilsen-South and Pilsen-North (Czech Republic). Landsc Ecol Eng, 13, 1.

Salvati L, Kosmas C, Kairis O, Karavitis C, Acikalin S, Belgacem A, Solé-Benet A, Chaker M, Fassouli V, Gokceoglu C, 2016. Assessing the effectiveness of sustainable land management policies for combating desertification: A data mining approach. J Environ Manage, 183, 754-62.

Sklenicka P, Hladík J, Střeleček F, Kottová B, Lososová J, Číhal L, Šálek M, 2009. Historical, environmental and socio-economic driving forces on land ownership fragmentation, the land consolidation effect and the project costs. Agricultural Economics, 55, 12, 571-82.

TRGM, 2017. Tarım Reformu Genel Müdürlüğü Verileri.

TÜİK 2014. Tarım Alanları.

TÜİK, 2017. Adrese Dayalı Nüfus Kayıt Sistemi 2017 Sonuçlar. Türkiye İstatistik Kurumu.

World population trends, 2017. UNFPA, https://www.unfpa.org/world-populationtrends.

Van den Noort PC, 1987. Land consolidation in the Netherlands. Land Use Policy, 4, 1, 11-3.

Van Huylenbroeck G, Coelho JC, Pinto PA, 1996. Evaluation of land consolidation projects (LCPs): A multidisciplinary approach. J Rural Stud, 12, 3, 297-310. 